Kelaniya Journal of Human Resource Management

Volume 10-Number 01-January 2015 \& Number 02-July 2015

\title{
Comprehensive Literature Review on Human Capital Investments Theory: What's in it?
}

\author{
Udaya Mohan Devadas \\ Department of Human Resource Management, Faculty of Commerce and \\ Management Studies, University of Kelaniya, Sri Lanka \\ mohanudaya395@gmail.com
}

\begin{abstract}
'Human Capital' (HC) is being widely used in different fields: economics, human resource development, and national planning with different meanings in different fields. Seemingly, the term has, in some instances, been misused in the literature and in the practice. In such a context, it is worthwhile to investigate into the development of HC theory. This study has been dedicated to elaborate the evolution of human capital investment theory, the content of $\mathrm{HC}$, the proxies of $\mathrm{HC}$, the benefits of human capital investment, the causes of human capital investment, and the limits of human capital investment theory. This study, hence paves the way for positioning human capital investments theory in the literature and to strategies HC development practices consciously rather approaching to it with gut feeling.
\end{abstract}

Keywords: Human capital investment, Human capital investment theory, benefits of human capital investments, causes of human capital $H C$, limits of human capital investments theory

\section{Introduction}

Human Capital (HC) has been viewed as a main driver in gaining economic progression of nations. Among the identified factors of production, labor was treated as a variable cost while the cost involved in physical capital as an investment in the production function. Later, many argued that production is not mere a function of labor with other factors and it can not be just identified in terms of number of heads or hours of working for the fact that it depends on the quality of labour (decided by the knowledge and skills pertained to labour) that can be further enhanced and developed. With the economic transformation of many western countries including the USA 
to more advanced societies from industrial zones, knowledge and skills were treated as the key determinants in enhancing the outputs at both micro and macroeconomic levels. On the other hand, the human civilization was greatly a matter of education with other factors and that the progressive economies in the west including the USA spent a huge amount of money on education. This phenomenon then became a focus of research from the late 1950's. Many empirical studies were carried out based on education or variables related to education. The first to identify education as a form of capital was Schultz, (1963, p.64) after his undecided remark that skills and knowledge become a form of capital or not (Schultz, 1961, p.1). With his focused studies, in 1960 and in 1964, Becker theorized the relationship between education and economic development or high income earnings using the external rate of return on education (Becker, 1960) and internal rate of return on education (Becker, 1964). With the emergence of this new ideological perspective, the term human capital has been using (or in some cases misusing) in the literature and in the practice. This literature review examines the development of human capital investment theory by discussing about its evolution, the content of $\mathrm{HC}$, the proxies of $\mathrm{HC}$, the benefits of human capital investment, the causes of human capital investment, and the limits of human capital investment theory.

\section{Evolution of Human Capital Theory Development}

The evolution of human capital (HC) theory has been considered in this article under four major eras of its evolution: classical economic thoughts of human capital; economic foundational studies of human capital; human capital theory building studies; and contemporary views of HC. Figure 1 depicts the alternative era of HC theory development. 


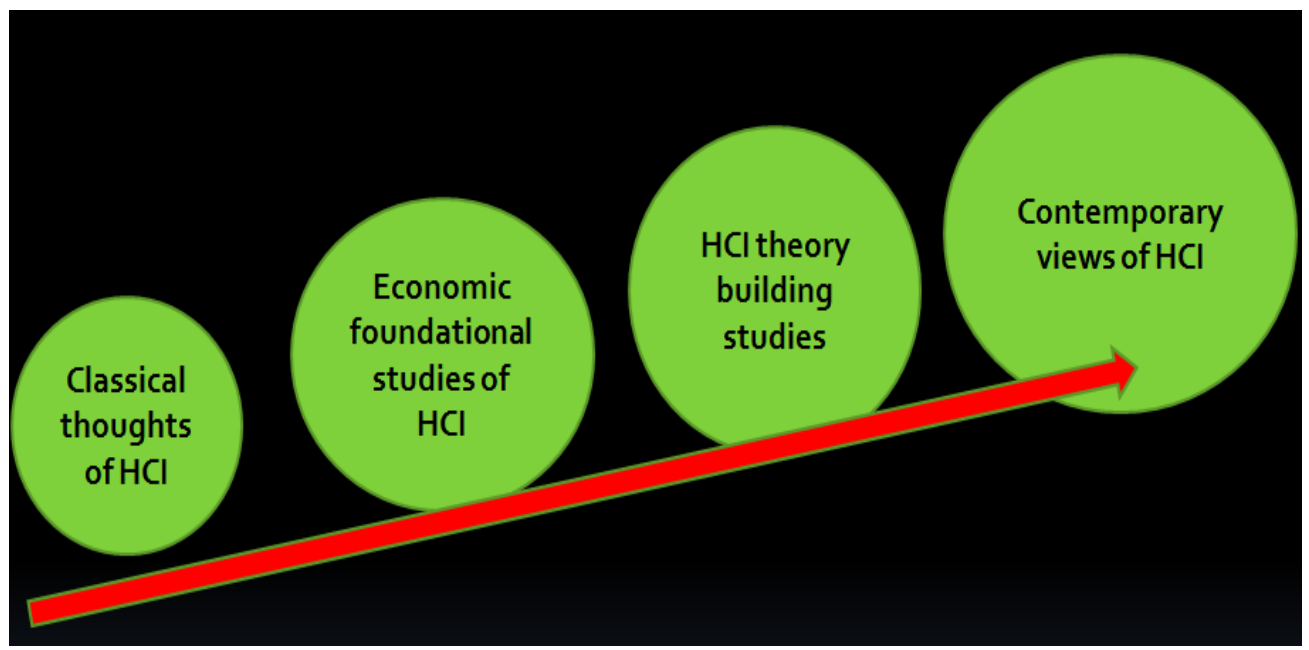

Figure 01: Evolution of Human Capital Investment Theory

Sweetland (1996) had reviewed the major HC literature under: early economic view points; economic foundation studies; and benchmark human capital theory studies. However, distinctively, this study considered the developments took place after 1990 under the contemporary views of HC to capture the studies carried out after Sweetland's work in 1996. Besides, the work after 1990s up to now seems to take a different shape by emphasizing on the inclusion of more accurate possible proxies of $\mathrm{HC}$, delineating new benefits of $\mathrm{HC}$ investments and, highlighting some notable limits of $\mathrm{HC}$ investment theory.

\subsection{Classical thoughts of Human Capital Investment}

The meaning of the term 'Human Capital' (HC) sought to be derived even from the days of the birth of economics. Adam Smith, known as the farther of economics, had treated human efforts as the root of all wealth as referred by Sweetland (1996).

Like Adam Smith, other most prominent economists such as John Stuart Mill, Alfred Marshall and Irving Fisher also addressed the matter of human capital. 
Sweetland (1996) referring to Alfred Marshall, stated that Marshall had considered human abilities as personal wealth, and it had been interpreted as capital, an agent of production. Further, Wöbmann (2003) quotes Marshall in his 'Principles of Economics', for his emphasis on investing in people as:

"The most valuable of all capital is that invested in human beings" (1890/1922, p. 564).

Sweeltand (1996) further referring to J.B. Mill stated that "Mill considered human abilities as economic utilities-means to wealth-liberally acknowledging all activities which lead to their improvement" (p.344).

According to Sweetland (1996) Fisher (1906) had implied that “...human participation in production processes constituted a form of capital..." (p. 344).

\subsection{Economic Foundational Studies of Human Capital}

Even though, the classical thoughts of $\mathrm{HC}$, attributed to delineate the concept of personal wealth-a form of capital as a cause of accumulating the wealth of a nation, it was not formally studied by classicalists until the commencement of economic foundational studies of HC. Some studies done by Jacob Mincer (1958), Soloman Fabricant (1959), Gary Becker (1960), and Theodore Schultz (1961) have been highlighted by Sweetland (1996) as significant studies carried out prior to the official establishment of HC theory in the early 1960s.

Mincer (1958) established a model to examine the nature and causes of personal income inequalities. Mincer (1958) showed that training and skill (HC) considerably affected personal income dispersions. Solomon Fabricant (1959) studied the productivity in the US from 1889 to 1957 and found that the methods and assumptions underlying productivity figures promoted underestimation of intangible capital investment eventually overestimating the productivity. By this discovery, he emphasized the importance of intangible capital to that he includes "....all the improvements in basic science, technology, business administration, and education and training..." (P.22). Gary Becker (1960) studied differentials in personal incomes between the college graduates and high school 
graduates in the US. His initial hypothesis was that a significantly higher rate of return on investments in college education than the rate earned on tangible capital represents an under-investment in college education where as the lower rate of return on investment in college education than that in tangible capital is attributable to an over-investment in college education. His study-design provided an important methodological insight in analyzing HC investments. Theodore Schultz (1961) predominantly identified the relationship of education to $\mathrm{HC}$ formation. He further synthesized that people's skills and knowledge is a form of capital although it is not obvious, and showed that education is an expenditure made to both consumption and investment to attribute to the increase in stock of education as double as the increase in national income during 1900-1956. Further, he briefly listed five major categories of human activities (investments) which lead to improved human capabilities: health facilities and services; on-the-job training; formally organized education at the elementary, secondary, and higher levels; study programs for adults; and migration of individuals and families to adjust to changing job opportunities.

\subsection{Human Capital Theory Building Studies}

The economic foundational studies did not directly work on HC empirically. Instead, they build the context for the development of $\mathrm{HC}$ theory by highlighting the contribution of education (training and skills) to personal income discrepancies (Mincer, 1958), importance of intangible capital (Fabricant, 1959), appropriate methodologies to study on HC (Becker, 1960), and relationship of education to human capital and other types of human capital (Schultz, 1961). HC theory building studies had directly focused on explaining the direct relationship between $\mathrm{HC}$ and growth/income. Sweetland (1996) had explained the contribution of Denison (1962), Schultz (1963), and Becker (1964) to HC theory development studies.

Denison (1962) attempted to explain United State's economic growth by using the aggregate production function model. Denison's estimates suggested that education and knowledge accounted for at least $43 \%$ of national income growth. Sweetland (1996) mentioned that in a study done by Denison in 1974 substantially had shown the same results. "Schultz 
(1963) attributed the economic activities on education as human capital forming, and that contributed to economic growth. Similar to Denison, Schultz also asserted that knowledge was contributor to economic growth associated with schooling. According to him, the largest portion of cost of schooling was borne by students and the students' personal return is higher than the social return of schooling. Becker (1964) diverged from the total returns approach that had been used by the previous two scholars to explore 'internal rates of return on investments in education and training' (derived from the economic return to education investments to cost of education). Becker (1964) then calculated an internal rate of return (private/personal) in education investment to be maintained by a country as 'more than 10 per cent'. He further showed the need of calculating a rate or estimation of social effect in education except to the personal/ private rate of return on education.

\subsection{Contemporary Views of Human Capital}

Becker's definition for $\mathrm{HC}$ is again put forward by himself in 1993 as ".....expenditures on education, training, and medical care etc., are investments in capital [human]" (p. 15-16). The establishment of HC theory by using education as a main proxy has been criticized for its limitations and has dealt with other proxies of education by the later studies. Further, the studies on $\mathrm{HC}$ have been expanded to delineate its links to other diverse macroeconomic variables except growth and output/national income. Importantly, $\mathrm{HC}$ has been elucidated by the quality of education (Wöbmann, 2003 \& Gundlach, 1997), the impact of learning on the job (experience), and the role of nutrition and health (Gundlach, 1997). Critics have also been raised to deal with the discussion on the quality of education; life-long job related learning, unemployment among higher formal credentials (Livingstone, 1997) in explaining the HC theory. Today, the HC denotes many dimensions and be quite a complex phenomena as referred by Hamid and Zaman (2000) to Natoli (2008). Further, Hamid and Zaman (2000), referring to Natoli (2008) have highlighted certain characteristics of $\mathrm{HC}$ that $\mathrm{HC}$ : is non-tradable and no market exists that would permit the exchange of $\mathrm{HC}$ assets (except in the case of slavery); has both qualitative and quantitative aspects; can be either general or specific; and contains 
external effects from the social environment and the institutional context in which they live, which continually shapes its acquisition.

\section{Content of Human Capital}

The composition of $\mathrm{HC}$ has been argued even from the economic foundational studies of $\mathrm{HC}$. The education has been the center of the HC analysis in all times while some other quantitative and qualitative aspects were presented to represent $\mathrm{HC}$ by later studies.

Adam Smith (1776) first illustrated the main proxy of HC as 'educated man' while others generally describe investment in people or labor as capital. By the economic foundational studies, $\mathrm{HC}$ has been defined using formal education in terms of years of schooling and informal education in terms of work experience (Mincer, 1958); basic science, technology, business administration, and education and training (Fabricant, 1959); return on investment in education (Becker, 1960); and activities on health facilities and services, on the job training, formal organized education at elementary, secondary and higher levels' education, and study programs for adults (Sultz, 1961).

The HC theory building studies strictly limited to the education and knowledge obtained through formal schooling as the center of discussion on HC in their empirical studies (Denison, $1962 \&$ Sultz, 1963). Becker (1964) uniquely used the return on education investment to cost of education in explaining the $\mathrm{HC}$ theory. The reason for using education as the prime human capital investment for empirical analysis was due to the fact that education was viewed as to contribute to health and nutritional improvements (Schultz, 1963), and education can be more empirically measured in quantitative costs and years of tenure (Johnes, 1993). The literature relating to human capital theory has dealt with several types and means of education such as formal education at primary, secondary, and higher levels (Cohn \& Geske, 1990), informal education at home and at work (Schultz, 1981), specialized vocational education at secondary and higher levels (Corazzini, 1967), and on-the-job training and apprenticeships (Mincer, 1974). In the contemporary work, HC seems to be defined in a broader manner to include more qualitative variables. Importantly, it has 
been shown the need of considering other factors with $\mathrm{HC}$ for its effective working.

Livingstone (1997) paid attention for such factors like the extent of the use of people's learning capacities through the institutions of organized education to gain greater amount of knowledge, the fairness in the incentive structures, the extent of the avoid of work load mismatches, the creation of workplace democratization, recognition of new forms of compensable work etc. In its application, some countries have initiated radically to include more qualitative variables in HC. In the Malaysian context, as presented in the official website of the Prime Minister's office of Malaysia HC has been referred to encompass factors such as confidence, noble values and high morality, ethicality, well-mannerism, discipline, dynamicity, innovation, creativity, healthiness, patriarchy, justice, progressiveness, resilience and competitiveness. Further, $\mathrm{HC}$ on an individual level encompasses individual's genetic inheritance, education, experience, and attitude about life and business (Bontis, 1998).

It is for the reason that $\mathrm{HC}$ is referred to more qualitative matters as mentioned above, the possibility to misuse the term is very high. Therefore, some scholars have viewed HC differently to human capability. Sen (1997) in his editorial remarks in the Journal of world development mentioned the difference of $\mathrm{HC}$ and human capability. Explaining the difference between $\mathrm{HC}$ and human capability, he refers to the benefits of education. In HC, education is a commodity production that can increase the output and personal income. Human capability gain through education is an additional benefit except the above that is created by the competencies gained by the learner to be in a competitive edge. Thus, the benefit of education that advances learner's capability exceeds its role as $\mathrm{HC}$ in commodity production. Further he explains that "the concept of $\mathrm{HC}$ which concentrate only on one part of the picture is certainly enriching move, but it needs supplementation. This is because human beings are not mere means of production, but also the end of the exercise" (Sen, 1997, p.1960). According to him, human capability serves as the means not only to economic production, but also to social development, people's well-being and freedom, influencing economic production, and social change. 
In the very recent past, the countries have been more focused on $\mathrm{HC}$ development in their national planning levels under which more focus has been given to develop education. Miyamoto (2003) has shown some policy initiatives to enhance basic education and post basic education of developing countries as HCD initiatives. According to Miyamoto (2003), the most celebrated policy initiative of 'education for all' launched in collaboration of international donors, governments, and NGOs. That targeted to increase access to education and quality of education and high adult literacy that have not yet achieved in the central Asia and sub-Sahara Africa that show low primary school enrolment, adult literary, and gender gaps. Miyamoto (2003) further points out that some developing countries have taken their own initiatives to increase access and quality of basic education in Indonesia, Singapore, El Salvador, Haiti, and Costa Rica. And, countries like Ireland, Korea, Singapore and Africa have taken some policy initiatives in enhancing upper secondary and tertiary education. According to Miyamoto's (2003) observation, EU member countries have taken initiatives in the creation of what is called a 'minimum learning platform' that each defines the areas of knowledge and competences needed in the forthcoming labor market.

\section{Proxies of Human Capital}

The foundational economic studies of $\mathrm{HC}$ had used total return of education (Mincer, 1958 \& Fabricant, 1959), and external return on education investment (Becker, 1960). Benchmarking HC theory building studies also had used total return on education (Denis, $1962 \&$ Sultz, 1963) and internal rate of return on education investment (Becker, 1964). 
Kelaniya Journal of Human Resource Management

Volume 10-Number 01-January 2015 \& Number 02-July 2015

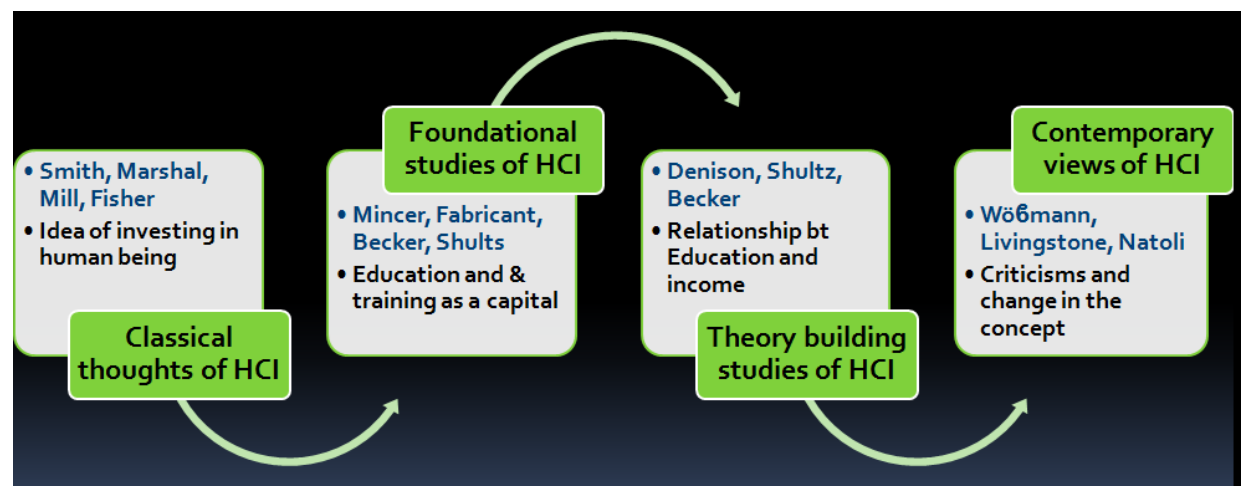

\section{Evolution of HCI theory development}

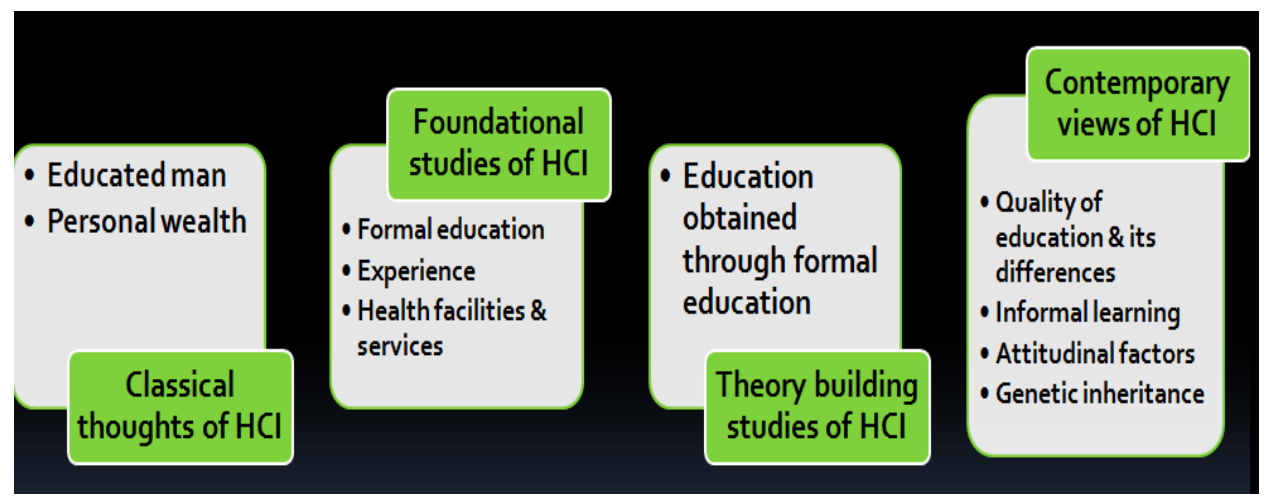

Content of HC

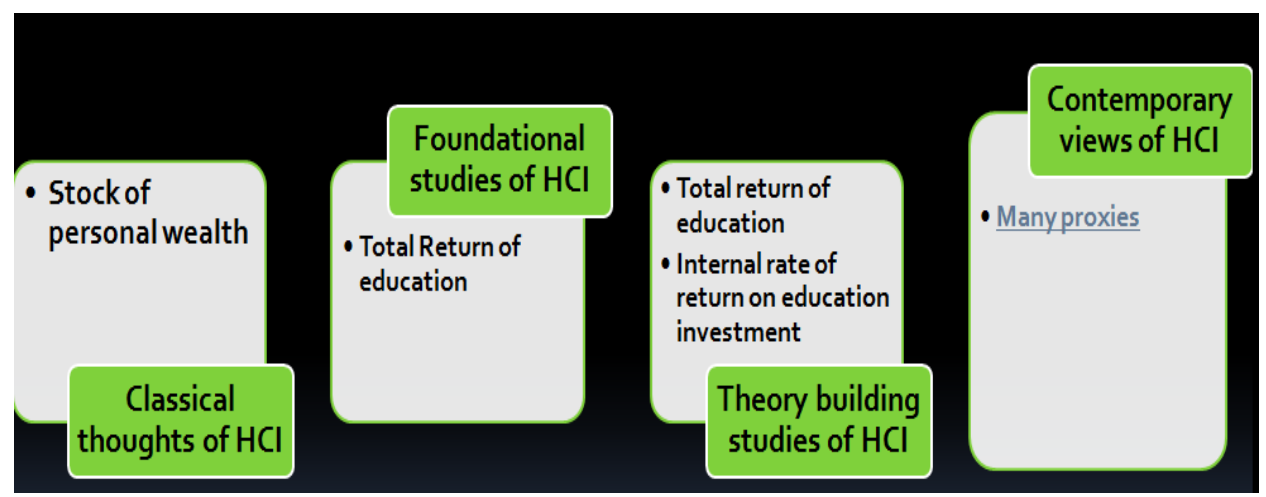

Proxies of $\mathrm{HC}$

\section{Figure 02: Summary of HCI Theory}

Source: Synthesized from Devadas and Silong (2010) 
As a contemporary study, Miyamoto (2003), in a study done with regard to the developing countries had used adult literacy rate, average years of schooling, net primary school enrolment ratio and educational attainment of post basic-schooling as HC proxies. According to Wöbmann (2003) school enrollment ratios, and average years of schooling of the working-age population have also been used in empirical growth research. To capture the quality of education, Wöbmann (2003) referred to some work of Barron (1991), Lee (1996), and Hanushek (1996) for their measures presented to proxy the 'inputs used per student' in the education system such as studentteacher ratio, government spending to education to GDP, educational expenditure per student, student teacher ratios, teacher salaries, and the length of the school years.

However, to show the differences of the quality of cross country education Wöbmann (2003) further presents the country-specific rate of return to education under certain assumptions of homogeneity of the country conditions (however, this ignores the qualitative differences in education). To consider the quality differences in education, direct measures of cognitive skills through the results obtained through test of cognitive achievement has been suggested. This is a result of Gundlach's (1997) work to shown the importance of international differences of quality of education, the impact of learning on the job (experience), and the role of nutrition and health in the successful accumulation of HC. Further, Goujon and Samir (2006) suggest using educational attainment as well to denote human capital. Figure 2 above, summarizes the evolution of $\mathrm{HC}$ Investment (HCI) theory, content of $\mathrm{HC}$ in different eras of $\mathrm{HCI}$ development, a proxies of $\mathrm{HC}$ as viewed under different views of HCI.

\section{Benefits/Outcomes of Human Capital Investments}

Benefits of $\mathrm{HC}$ were perceived even by the early economists. The classicalists' view was that $\mathrm{HC}$ mediated in creating the wealth to a nation. Foundational studies of economies and HC theory building studies showed the increased personal incomes (Mincer, 1958 and Becker, 1960, and Becker, 1964), national productivity (Fabricant, 1959), and national income and economic growth (schultz, 1961, Denison, 1962, and schultz, 1963). 
The following discussion shows the benefits of $\mathrm{HC}$ as derived by contemporary studies.

\section{Development and Growth}

Education under $\mathrm{HC}$ is crucial in determining the national growth and development and regional development. According to Baker \& Holsinger (1996), there is ample evidence to corroborate the basic human capital argument that school expansion amplifies the national development providing evidence to the fact that the payoffs from human capital development have been multiple and interconnected in several ways. According to Baker and Holsinger (1996), first, the provision of mass education of reasonable quality had an impact on economic growth both for some parts of Asia and elsewhere in the world. Second, education can influence health and demographic factors that promote the economically favorable trends of lower fertility, lower dependency ratios and so forth. Finally, other individual behaviors such as income investment and savings are associated with high educational attainment. Baker \& Holsinger (1996) further highlights the central role played by education as national human capital formation through the expansion of formal schooling in regard to rapid and sustainable economic growth in Japan and Asian Tigers. Further they highlight that human capital development has underpinned a set of economic, political, and social trends such as productivity growth in agriculture, high rates of manufactured exports, sustained and deep declined in human fertility, high rates of domestic saving, and increases in labor productivity that brought the development 'miracle' in Japan and Asian Tigers.

Outreville (1999) also found, in a cross country study of 57 developing countries, that human capital together with socio-political stability is crucial to explain the level of financial development. Pattern of economic development also is determinable by the distribution of $\mathrm{HC}$ and its interaction with technological progress, and economic growth (Galor \& Tsiddon, 1997). The utilization of regional favorable endowment of $\mathrm{HC}$ can tap the growth potential with the implementation of growth-enhancing economic reforms as shown by Foders (1998) by discussing possible strategies to avoid the likely fallen of Eastern Europe into a 'poverty trap'. Mathur (1999) also supported Foders agreeing that accumulation and 
promotion of $\mathrm{HC}$ is viable and promising strategy for regional economic development. He further says that $\mathrm{HC}$ has directly contributed to development by directly accumulating the knowledge stock of the region.

Mathur (1999) further highlights the indirect contribution of HC to regional development by increasing the productivity of other workers and capital, promoting agglomeration of economies, and stimulating house hold investments in children that ultimately contribute to growth and development. However, as empirically examined by Eicher and GarciaPenaloasa (2000), the stock of educated workers (HC) has a dual role of determining both the degree of income inequality and the rate of growth. In this case, the parameters of the demand for and the supply of labor are crucial determinants of whether inequality increases or decrease as an economy accumulates human capital. Further they claim that a trajectory of a country is dependent on the direct cost of education, the extent of externalities in the education process, and the elasticity of substitution between skilled and unskilled workers in production. Differently, Kyriacou (1991) has found that the growth of HC was not related to growth of output (although, the initial HC levels had positively related to future output growth) when he estimated the cross country Cobb-Douglas production for the period for 1970-1985 measuring both input and output in growth rates. The reasons for why only the level of $\mathrm{HC}$ matters not growth rate of $\mathrm{HC}$ to output growth were: first, that the output elasticity of $\mathrm{HC}$ is positively related to the human capital level. In other words a country can not have a significant positive contribution of education to growth unless it has already attained a level of HC stock. Second, that the level of average $\mathrm{HC}$ is a proxy for the growth of technology. That means that, the growth of $\mathrm{HC}$ contribute to growth through the technology, so that, the results come as the growth of technology is omitted. He concluded that education contributes the growth of output when the sufficient level of per capita HC stock gets accumulated. Alternatively, Ranis and Stewart (2000) have shown two connections from Economic Growth (EG) to Human Development (HD) by proxying HD in terms of the expenditure on health and education that are also the proxies of $\mathrm{HC}$ as shown by the literature. With empirical evidence, this study shows that countries initially favoring EG end up with poor performance in HD leading to poor growth performance that depresses HD achievements and so 
on. Ranis and Stewart (2000) further claim that countries with good HD and poor EG sometimes show growth that eventually leads good HD and so on.

Another result of $\mathrm{HC}$ is increasing total factor productivity. As shown by Engelbrecht (1997), general human capital affects Total Factor Productivity (TFP) as a factor of production, and as a vehicle for international knowledge transfer associated with productivity catch-up amongst economies in the Organization for Economic Corporation and Development (OECD). Erosa, Koreshkova, and Restuccia (2007) have also found that human capital accumulation strongly amplifies TFP differences across countries.

\subsection{Social Benefits}

Another set of studies have elucidated the impact of HC on social and political development. Miyamoto (2003) had done a cross section and timeseries analysis covering different sets of developing countries on the relationship between FDI and HC. He covered two periods: covering the period between the database available between 1960s and 1980s; and datasets available between the 1980s and mid-1990s. He concluded that both the stock and flow measures of the human capital variable showed positive effect on FDI inflows due to the reason that most MNEs operating in developing countries during the late 1980s and 1990s mainly had focused on efficiency and/or subcontracting that demanded high skilled labor force. Except to the contribution of HC to FDI's, HC had contributed to civil liberties, political stability, health and reduced crime/corruption that are considered to be necessary determinants for FDI. Swanson \& King, (1991) referring to Becker (1993) pointed out that education on the other hand, contributes to improve health and nutrition; controlling the growth of the population; increasing the overall quality of life. It further helps establish democratic and legal due processes and to pursue values such as equality, fraternity, and liberty at both private and social levels.

\section{Development of Intellectual Capital}

HC has contributed to the development of intellectual capital. Bontis (1998) has pointed out by his empirical pilot study that human capital is a significant component forming the intellectual capital in organizations and it interact with other two component of intellectual capital namely 'structural 
capital' that is the tacit knowledge embodied in organization itself and the 'customer capital' that refers to the knowledge of market channel and customer relationships. Bontis (1998) also referring to Hudson (1993), has shown how $\mathrm{HC}$ is important as a source of innovation and strategic renewal.

The above discussion on contemporary views on HC's benefits can be synthesized as presented in Figure 03.

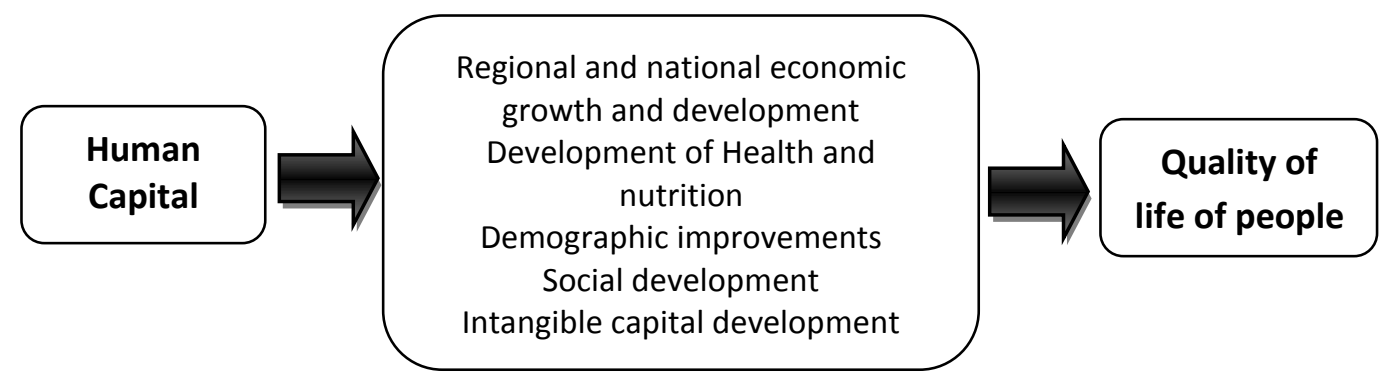

\section{Figure 03: Synthetization of HC's Benefits}

\section{Causes of Human Capital Investments}

The HC theory development studies and economic foundational studies of HC have not directly discussed about the specific causes that develop HC. Anyway, it is indirect that the enhancement of the proxies of $\mathrm{HC}$ ultimately causes to HC. However, in the contemporary studies, some specific forms of causes to HC have been discussed. Among them, Mincer's work on elucidating the sources from supply side and demand side of human capital growth carries high importance. As the supply side forces to HC growth, Mincer (1995) names some resultants of the social transformation such as the growth of family income, increased cost of time, urbanization and increased city living, demographic transitions, and the changing roles of women in the market and in the family. These supply side factors alone can not grow further $\mathrm{HC}$ as it involves a self limiting decline in rates of return of education below those in alternative investments. Such decline can be offset by the factors in the demand side of the growth of HC such as capital accumulation and technological changes that demands skilled labor (evident by change in skills and wage structures in the labor market) as a result of the demand raised for their main product or service created in the market. 
According to Mincer (1995), this reciprocal relation between economic growth and the human capital growth is a vital key for sustained economic growth, yet a caveat may be applied to indirect effects of economic growth (such as more women participation in the labor market) on family instability which may lead to a deterioration of childhood human capital in some societies as researches have shown negative impact of family instability on child development. Figure 4 depicts this reciprocal relationship between economic growth and HC growth. Ranis and Stewart (2000) also have shown that economic growth can lead to the development of education and health, and human development.

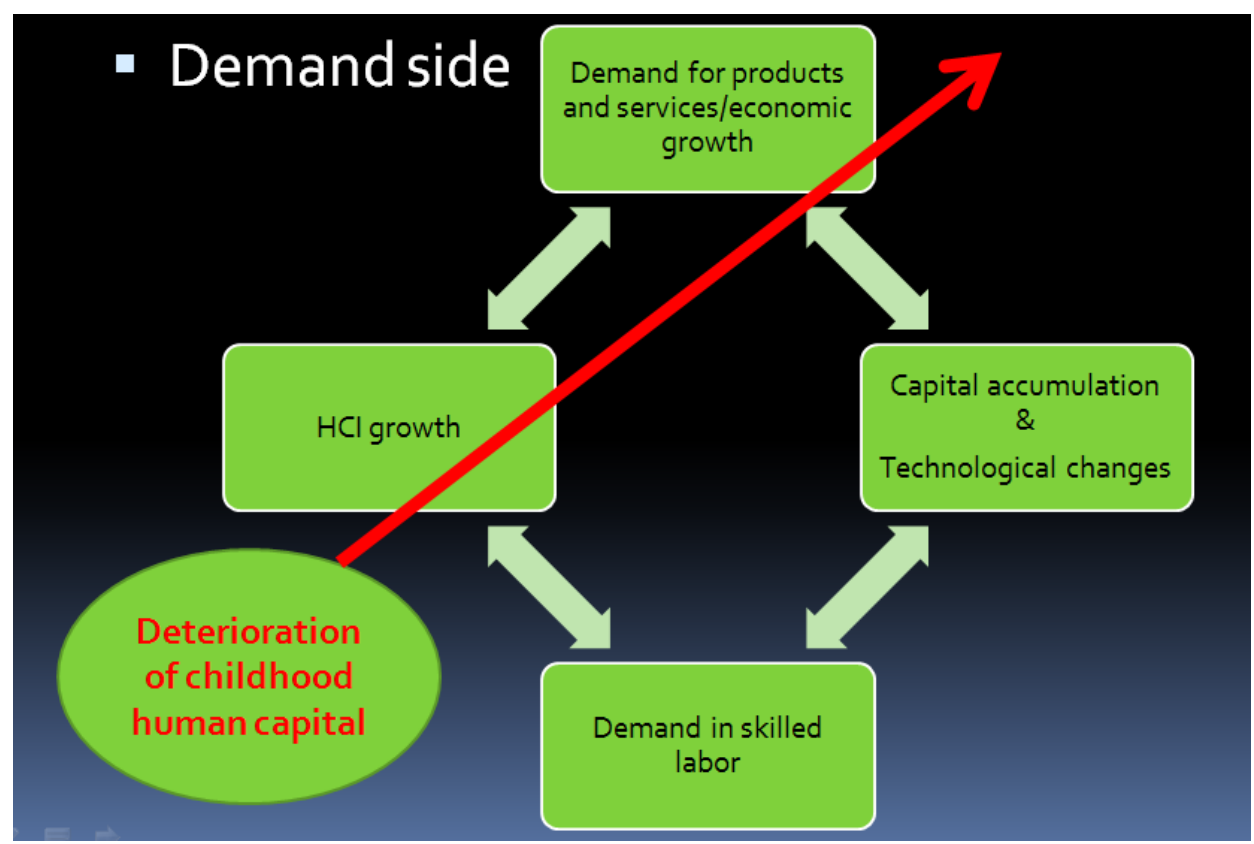

Figure 04: Mincer's (1995) Supply side and demand side forces

Galor and Tsiddon (1997) have discussed about a cause of HC formation-an interplay between a local home environment externality and a global technological externality that decide the human capital distribution, and simultaneous determination of evolutionary pattern of the income distribution, and economic growth. They concluded that local home environment externality is dominating in early stages of development, so that the distribution of income becomes polarized whereas global 
technological externality dominates in mature stages of development leading to a contraction of income distribution. Further in this study, local home environment externality has been meant by the functional relationship between an individual's levels of human capital with parental level of HC (parental educational inputs). And, global technological externality has been meant by technological progress or the rate of adoption of new technologies-an individual's ability to adapt to an environment characterized by technological change. Both of these phenomena also play as causes of HC.

Beine, Docqier, and Rapoport (2001) highlighted the importance of migration prospects in making education decisions and $\mathrm{HC}$ formation. They found that two effects are important to HC development in a small, open, and developing economy. First 'brain effect' that says that investment in HC increases as it is fostered by the migration opportunities that offer higher expected return in abroad when the economy is open. Second is the 'Drain effect' that talks about the departure of some educated agents that reduces the HC stock. They further explain about a beneficial brain drain (BBD) that can occur when the brain effect is dominating.

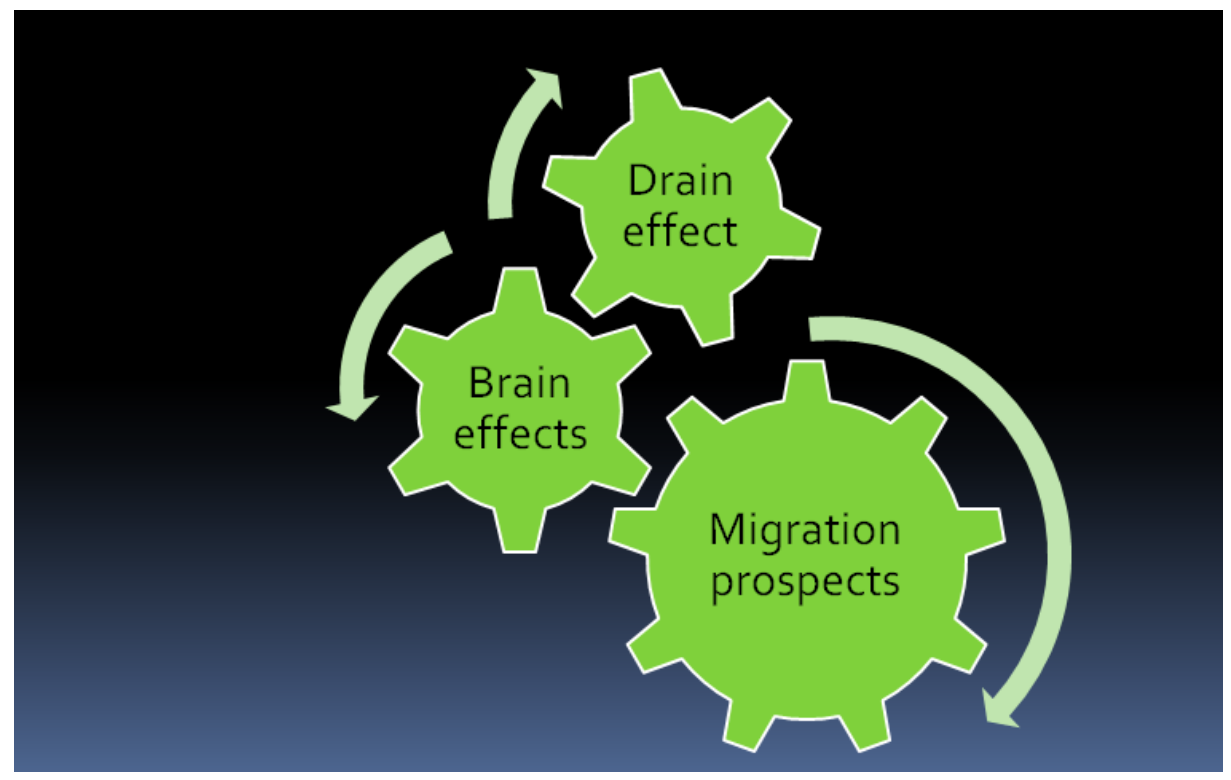

Figure 05: Causes of HCI- Beine, Docqier, \& Rapoport (2001) 
At policy level, they direct to consider about subsidies to education that can be inefficient if the probability of leaving is high for the educated. According to their argument, if the expected return to education is high, there is no need to give subsidy to forester HC. Figure 5 illustrate this phenomenon.

As Miyamoto (2003) shows, FDI contributes to develop stock of HC in the host countries through MNEs themselves as they actively involve in providing education and training, new skills, information and technology to host countries that ultimately, leads to host countries to experience continuous inflow of FDI over time by increasingly attracting higher valueadded MNEs, while at the same time upgrading the skill contents of preexisting MNEs and domestic enterprises.

\section{Limits of Human Capital Investment Theory}

Limitations of HC theory can be discussed in terms of its conceptual and methodological aspects.

\subsection{Conceptual Ambiguity}

Explaining the HC's conceptual limitations, Livingstone (1997) criticizes some human capital advocate's suggestions that greater increase in learning efforts does not lead to commensurate economic gain because of declining of quality of the education. Instead, he showed that what really happens is not the declining of quality of education in his evidence but, people in advanced industrialized market economies were increasingly using their learning capacities through the institutions of organized education to gain greater amount of knowledge.

Another argument of human capital revisionists is that informal work related learning and their cumulative bodies of tacit knowledge can highly compensate. Livingstone (1997) showed that the most poorly paid employees also devote as much effort to work related learning as mostly paid employees. So, the challenge is to establish fair incentive structures, especially among industrial and service workers as they lacked of opportunity to apply their acquired knowledge in the work. Thirdly, he disproved the $\mathrm{HC}$ advocate's argument that those with the most formal 
education can get good jobs attributing to the diminishing credibility of the above relationship among the growing population of under-employed and unemployed youth population. He further suggests some remedies to over come the education-job gaps by: reducing the waste of knowledge and skills of educated workers at work by economic reforms in terms of redistribution of current paid work to eliminate work load mismatches; workplace democratization that permit under employed to utilize their knowledge and skills fully in the design and control of the work process; and by recognizing the new forms of compensable work to legitimate socially useful labor rather focusing only in improving learning. Foders, (1998) highlights some conceptual issues in HC research in determining: (1) the optimum quantity and quality of $\mathrm{HC}$ necessary for sustainable growth; (2) who should pay for education; and (3) whether education should always pay off in terms of economic growth only among the other purposes of education as a consumer good and as a screening device to see bright and capable people from others, except its mostly highlighted purpose; education as an investment.

\subsection{Methodological Imperfection}

Sweetland (1996), in detailed, discusses some criticisms against HC theory. The most plausible criticism out of them is the methodological imperfections. Sweetland (1996) referred to Benson (1978), for his criticisms on the underlying assumptions of HC methodology: first education helps develop skills of work; and second, earned income reflects marginal productivities of different categories of workers. Benson (1978) showed the ignorance of the role of on-the-job training regarding first assumption, and attributed to the fact that salary and wage differentials reflect not differences in performance, but the differences in educational attainments. In a study done by Abramovitz (1962) reviewing a study conducted by Denison (1962) on the production function suggested that indexes constructed to represent variables in the function inherently assumed qualitative homogeneity that is not in reality. Mincer (1963) suggested that the missing external and non-pecuniary elements associated with statistical constructs created theoretical inconsistencies, especially when optimal educational investment questions were considered. Benson (1978) further claims that the greatest limitation of the rate of return method 
was imposed by its basic education and income levels' formula. He asserted that "this formula tends to overestimate the contribution of education to economic growth by inadequately accounting for other important influences such as ability". Erosa, Koreshkova, \& Restuccia, (2007) also highlights that in using Mincer-returns to measure human capital understates differences across countries because, Mincer-returns do not capture differences in schooling quality across countries.

\section{Definitional Deformation}

In the recent work in the academia and in the practice, the terms HCD and HRD have been interchangeably used. Sometimes, both have been equalized to each other, especially, to describe the HRD interventions at national policy level. It needs a debate on equalizing HRD to HCD. However, the recent studies' identification to equalize HRD and HCD is noteworthy.

Yang et., al. (2004) said that human resource development and human capital development are indistinguishable in the China's context as the two concepts were introduced to China in recent years and are often used interchangeably. In the context of India, Rao \& Varghese (2009) have not equalized the two concepts; instead, they have seen HRD's outcomes as to the contributions of the development of HC. In the contests of Gulf countries, The HCD and HRD seem to be used interchangeably with no any rationalization as did in the above two cases (Achoui, 2009). Further, Achoui (2009) used the term HD to picture the HRD in Saudi Arabia because of lack of evidence on HRD. Osman-Gani \& Chan (2009) have identified some challenges in Singapore's HCD again equalizing HRD to HCD. The use of these terms in the Asia's context is different from what the $\mathrm{HC}$ investment theory elucidated. $\mathrm{HC}$ investment theory took only an economic perspective. It is however questionable the use of the same concept of HC investment as HCD in HRD to explain HRD phenomenon that is not limited only by economic sphere. Swanson (2001) identified HC investment theory as a sub theory under economic theories of HRD's foundational theories. Therefore, how the 'HC investment' has been used as HCD by equalizing it to HRD is debatable and the reasons for such construct in different country contexts are study worthy. 


\section{Conclusion}

The human capital investment theory has so far been developed under four major eras with; a changing focus in the content of $\mathrm{HC}$ and its proxies to encompass varied dimensions, a realization of more benefits of investments in $\mathrm{HC}$ and the causes to it, and the revelation of new limits of the human capital investments. It was also shown that the meaning of human capital is changing from mere investments in education to many other concerns related or unrelated to education. Especially, the contemporary studies have shown the deviation of the conceptual configuration of the term HC and, have identified the implications of $\mathrm{HC}$ beyond its contribution to national income and/or the growth. This shift of defining $\mathrm{HC}$ in a broader manner seems to impact on the future research and the practice.

Further, such deviation is inherited in the interpretational process in different country contexts with regard to $\mathrm{HC}$ investments. Importantly, some countries including Malaysia provide outstanding examples for such broad expose of the term HC. However, the use of terms such as HCD, $\mathrm{HRD}, \mathrm{HD}$, and $\mathrm{HC}$ investments should be placed onto its appropriate knowledge base, while elucidating their real meaning without misusing the terms inappropriately for the reason of others using such terms. Further studies are needed to verify the appropriateness of using the terms HCD and HRD interchangeably while discovering the causes for such constructions in different country contexts.

\section{References}

Abramovitz, M. (1962). Economic growth in the United States [review of the book: The sources of economic growth in the United States and the altanatis before us]. The American Economic Review, 52, 762782 .

Achooui, M.M. (2009). Human Resource Development in Gulf countries: An analysis of the trends and challenges facing Saudi Arabia, Human Resource Development Review, 12, 35-46. 
Baker, P.D. and Holsinger, D.B. (1996). Human Capital Formation and School Expansion in Asia; Does a Unique Regional Model Exist? International Journal of Comparative Sociology, 37, 159-173.

Becker, G. S. (1960). Underinvestment in college education? The American Economic Review, 50, 346-354.

Becker, G. S. (1964). Human capital: A theoretical and empirical analysis, with special reference to education. New York: National Bureau of Economic Research.

Becker, G. S. (1993). Human capital: A theoretical and empirical analysis, with special reference to education (Third Edition). Chicago and London: University of Chicago Press.

Beine, M., Docquier, F., \& Rapoprt, H. (2001). Brain drain and economic growth: theory and evidence. Journal of Development Economics, $64,275-289$.

Benson, C.S. (1978). The economics of public education ( $3^{\text {rd }}$ ed.), Boston: Houghton Mifflin.

Bontis, N. (1998). Intellectual Capital: An Exploratory Study that Develops Measures and Models. Management Decision, 36 (2), 63-776.

Cohn, E., and Geske, T.G. (1990). The economics of education ( $3^{\text {rd }}$ ed.). New York: Pergamon Press.

Corazzini, A.J. (1967). When should vocational education begin? The Journal of Human Resources, 2, 41-50.

Denison, E.F. (1962). The source of economic growth in the United States and the alternatives before us. New York: Committee for Economic Development.

Davadas U.M., \& Silong, A.D. (2010). Development of Human Capital Theory. Proceedings of $9^{\text {th }}$ International Conference of the Academy of HRD (Asia Chapter), November, 11-13, Shanghai, China.

Eicher, T., \& Garcia-Peñalosa, C. (2000). Inequality and Growth: The Dual Role of Human Capital in Development. Munich: CESifo. 
Engelbrecht, H.J. (1997). International R\&D spillovers, human capital and productivity in OECD economies: An empirical investigation, European Economic Review, 41(8), 1479-1488.

Erosa, A., Koreshkova, T., \& Restuccia, D. (2007). How Important is Human Capital? A Qantitative Theory Assesment of World Income Inequality. JEL Classification, 1.

Fabricant, S. (1959). Basic facts on productivity change. New York: National Bureau of Economic Research.

Foders, F. (1998). A Note on Economic Growth and Human Capital in Eastern Europe. Dusternbrooker Weg : The Kiel Institute of World Economics.

Galor, O., \& Tsiddon, D. (1997). The Distribution of Human Capital and Economic Growth. Journal of Economic Growth , 2, 93-124.

Goujon, A., \& Samir, K. C. (2006). Past and Future of Human Capital in Southeast Asia: From 1970 to 2030 . Vienna: Vienna Institute of Demography.

Gundlach, E. (1997). Human Capital and Economic Development:A Macroeconomic Assessment. Intereconomics , 23-35.

Gundlach, E. (1997, January/February). Human Capital and Economic Development: A macroeconomic Assessment. INTERECONOMICS , pp. 23-35.

Hamid, N. A., \& Zaman, H. B. (2009). Framwork of Malaysian Knowledge Society: Results form Dual Data Approach. World Academy of Science, Engineering and Techonology, 58, 343-347.

Johnes, G. (1993). The economics of education. New York: St. Martin's Press.

Kyriacou, G. A. (1991). Level and Growth effects of Human Capital: A cross-Country Study of the Convergence Hypothesis. New York: C.V Star Centre for applied Economics. 
Kelaniya Journal of Human Resource Management

Volume 10-Number 01-January 2015 \& Number 02-July 2015

Livingstone, D. W. (1997). The Limits of Human Capital Theory:

Expanding Knowledge, Informal Learning and Underdevelopment. Policy Options , 9-13.

Mathur, V. K. (1999). Human Capital - Based Strategy for Regional Economic Development. Economic Development Quarterly, 13 (3), 203-216.

Mincer, J. (1958). Investment in human CapitaLand personal income distribution. The Journal of Political Economy, 66, 281-302.

Mincer, J. (1974). Schooling, experience, and earnings. New York: Colombia University Press.

Mincer, J. (1995). Economic Development, Growth of Human Capital, and the Dynamics of the Wage Structure. Journal of Economic Growth, $1,29-48$.

Miyamoto, K. (2003). Human Capital Formation and Foreign Direct Investment in Developing Countries. OECD Development Centre.

Natoli, R. (2008). Indicators of economic and social process: An assessment and an alternative. Doctoral thesis, School of Applied Economics, Faculty of Business and Law, Victoria University, Melbourne, Australia.

Osman-Gani, A.M. and Chan, T.H. (2009) Trends and Challenges of Developing Human Capital in Singapore: an Analysis of Current Practices and Future Potentials. Human Resources Development International, 12(1), 47-68.

Outreville, J. F. (1999). Financial Development, Human Capital and Political Stability. Geneva: UNCTAD.

Prime Minister's Office of Malaysia. Human Capital Development.

Retrieved January 22, 2010, from

http://www.pmo.gov.my/humancapital/index.html

Ranis, G. and Stewart, F. (2000). Economic Growth and Human

Development, World Development, 28(2), 197-219. 
Kelaniya Journal of Human Resource Management

Volume 10-Number 01-January 2015 \& Number 02-July 2015

Schultz, T. W. (1961). Investment in human capital [Presidential address delivered at the annual meeting of the American Economic Association, Saint Louis, MO, December, 1960]. The American Economic Review, 51, 1-17.

Schultz, T. W. (1963). The economic value of education. New York: Columbia University Press.

Schultz, T.W. (1981). Investing in people: The economics of population quality. Los Angeles: University of California Press.

Sen, A. (1997). Editorial: Human Capital and Human Capability. World Development , 25 (12), 1959-1961.

Swanson, A.D., \& King, R.A. (1991). School Finance and Practice. New York: Longman.

Swanson R. A. (2001). Human Resource Development and its Underlying theory. Human resources Development International, 4(3), 299312 .

Sweettland, S.R .(1996). Human Capital Theory: Foundations of a field of Inquirey. Review of Educational Research,66, 341-359.

Rao, T. V., \& Varghese, S. (2009). Trends and challenges of developing human capital in India. Human Resource Development International 12(1) $15-34$.

Wöbmann, L. (2003). Specifying Human Capital. Journal of Economic Surveys , 17 (3), 240-270.

Yang, B., Zang. D., and Zang, M. (2004). National Human Resources Development in the Republic of China. Advances in Developing Human Resources, 6(3), 297-306. 